\title{
PENERAPAN STRATEGI PEMBELAJARAN SFAE DAN ENE DALAM MENULIS KARANGAN DI SMK NEGERI I TELUK MENGKUDU DESA SIALANG BUAH KABUPATEN SERDANG BEDAGAI
}

\author{
${ }^{1}$ Mimi Rosadi, ${ }^{2}$ Sujarwo \\ Universitas Muslim Nusantara (UMN) Al-Washliyah \\ 1'mimirosadi@gmail.com²sujarwoumnaw@gmail.com
}

\begin{abstract}
Abstrak
Mengenai hal tentang pendidikan di Sialang Buah saat ini khususnya satu sekolah yang terdapat di sana yaitu SMK Negeri 1 Teluk Mengkudu, masih kurangnya pendidikan karakter yang diterapkan oleh guru kepada siswa serta penggunaan strategi pembelajaran yang terlalu monoton dengan model ceramah. Hal ini membuat siswa kurang aktif dalam pembelajaran karena hanya mengandalkan guru dalam memahami materi-materi yang diajar.Usaha sadar yang dilakukan oleh seorang guru dapat mempengaruhi karakter yang mereka miliki. Pendidikan karakter tersebut dapat diwujudkan dalam kegiatan proses pembelajaran dengan menerapkan strategi pembelajaran yang dapat membantu siswa untuk mempermudah belajar mereka khususnya mata pelajaran bahasa Indonesia dalam menulis karangan. Penerapan strategi pembelajaran yang akan diterapkan dalam pembelajaran menulis karangan yaitu kombinasi antara strategi pembelajaran SFAE dan ENE. Dalam hal ini pengusul berupaya untuk memperkenalkan startegi pembelajaran yang mengkombinasikan strategi SFAE dengan ENE dalam mencapai hasil karangan yang baik.Strategi pembelajaran SFAE merupakan strategi yang mengarahkan siswa untuk mempresentasikan ide atau pendapatnya secara inovatif (Purnitawati, 2011:21).Siswa diarahkan untuk menyampaikan pendapatnya setelah mendengarkan penjelasan dari guru.Strategi SFAE dikombinasikan dengan strategi ENE dimana siswa diarahkan untuk memperhatikan sebuah gambar yang ditampilkan dari OHP atau gambar-gambar dari guru kemudian dituliskan ke dalam bentuk karangan dengan menggunakan strategi pembelajaran SFAE.
\end{abstract}

Kata Kunci: Strategi Pembelajaran, Sfae, Ene, Menulis Karangan

\begin{abstract}
Regarding the matter of education in Sialang Buah currently, especially one school located there is SMK Negeri 1 Teluk Mengkudu, still the lack of character education applied by the teacher to the students and the use of learning strategies that are too monotonous with the lecture model. This makes the students less active in learning because they only rely on teachers in understanding the material being taught. Conscious effort made by a teacher can affect the characters they have. Character education can be realized in the learning process activities by implementing learning strategies that can help students to facilitate their learning, especially Indonesian subjects in writing essays. Implementation of learning strategies that will be applied in learning writing essay is a combination of learning strategies SFAE and ENE. In this case the proposer seeks to introduce a learning strategy that combines SFAE strategy with ENE in achieving good results. SFAE learning strategy is a strategy that directs students to present their ideas or opinions innovatively (Purnitawati, 2011: 21). Students are directed to express their opinions after listening to the teacher's explanation. The SFAE strategy is combined with the ENE strategy whereby the students are directed to consider an image shown from the OHP or the drawings of the teacher and then written in the form of essays using the SFAE learning strategy.
\end{abstract}

Keyword: learning strategy, sfae, ene, writing authorship 


\section{PENDAHULUAN}

Sialang Buah, nama sebuah pantai yang terletak tidak jauh dari kota medan namun tetap memberikan ketertarikan tersendiri bagi orang yang haus menikmati keindahan alam. Pantai ini sempat memberikan semangat hari ini untuk melangkahkan kaki ku menuju kehamparan pasir putihnya yang begitu menawan. Memang awalnya aku pernah beberapa kali kesana, itupun karena aku

terlibat dengan suatu proyek perencanaan kawasan wisatapada saat aku bekerja di kantor konsultan pada tahun 2008. Sekarang tepat tanggal 14 Februari 2010 yang berarti hampir 2 tahun aku tidak melihat pantai yang terkenal dengan hamparan pasir pantai, jembatan peninggalan sejarah, dan juga aktifitas nelayan yang kembali dengan hasil tangkapanya dari laut. Luar biasa menakjubkan dan membuat aku ingin sekali ini kembali mengenang masa itu.

Sialang Buah salah satu pantai dari sekian banyak pantai yang ada di kabupaten serdang bedagai Sumatera Utara. Pantai Sialang Buah termasuk pantai yang banyak dikunjungi wisatawan baik lokal maupun luar setelah pantai cermin. Disekitar Pantai Sialang Buah ada beberapa pantai yang tak kalah menarik, seperti Pantai Klang, L.Sigambar, T.R. Dewi, dan Tuntungan. Pantai Sialang Buah merupakan dataran pantai yang tertetak antara $0-8$ meter dari permukaan laut, dan kemiringan 0

- 8\%. Wilayah desa pantai Sialang Buah memiliki lahan seluas $201 \mathrm{Ha}$. Desa Pantai Sialang Buah merupakan Ibu kota dari Kecamatan Teluk Mengkudu. Kawasan wisata terletak 1300 meter dari pemukiman penduduk.
Berdasarkan histori yang diceritakan oleh penduduk yang berada disekitar pesisir pantai, Pantai ini dahulu sering digunakan oleh para Pasukan TNI untuk berlatih dan mendidik ketangkasan mereka. Setelah beberapa lama barulah pemerintah berinisiatif untuk mengelola pantai menjadi objek wisata agar bisa dimanfaatkan oleh pengunjung yang tertarik. Pada saat terjadi peristiwa gelombang tsunami, pantai ini juga menerima dampak yang sukup besar seperti daerahdaerah lainnya yang ada di pesisir pantai. Walau korban jiwa tidak sebanyak seperti yang ada di aceh, namun peristiwa tersebut juga cukup menghancurkan fasilitas yang ada disana. Jembatan yang tadinya terlihat memberikan landmark terhadap kawasan ini juga menjadi rusak akibat terjangan gelombang tsunami tersebut.

Jembatan yang dulu terlihat eksotis dan memiliki nilai sejarah, pada saat ini malah diganti dengan jembatan yang sangat konvensional tanpa sentuhan seni sedikitpun. Jembatan yang dibangun sekarang hanya terdiri dari besi-besi kaku yang menjadi rangka untuk menopang permukaan jembatan dari kayu tersebut. Kalau untuk sekedar menjadi akses penghubung antara area parkir dengan area wisata pantai, mungkin jembatan tersebut dapat dikatakan strategis. Namun keberadaannya tidak akan menjadi daya tarik untuk pengunjung. Disini lah sebenarnya peran pemerintah untuk bisa membuat fasilitas yang bisa meningkatkan minat pengunjung.Pantai Sialang Buah memiliki potensi yang luar biasa. Bila kita kaji lebih jauh beberapa potensi tersebut dapat diolah sehingga 
menghasilkan nilai plus untuk kawasan tersebut. Adapun Potensi yang ada tersebut antara lain :

- Letaknya strategis antara kota Medan dan kota Tebing Tinggi

- Udara Segar dan belum mengalami polusi yang berat

- Tidak terdapat hal yang berbahaya seperti ikan paus

- Penduduknya ramah akan masyarakat wisatawan.

- Hari libur dan hari Minggu ramai dikunjungi wisatawan domestik

- Pukulan ombak yang sudah dapat

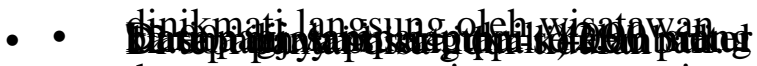
dengan santai, pantainya mengandung pasir kuarsa yang dapat digunakan sebagai bahan baku kaca.

Mengenai hal tentang pendidikan di Barusjahe saat ini khususnya satu sekolah yang terdapat di sana yaitu SMK Negeri 1 Teluk Mengkudu masih kurangnya pendidikan karakter yang diterapkan oleh guru kepada siswa serta penggunaan strategi pembelajaran yang terlalu monoton dengan model ceramah. Hal ini membuat siswa kurang aktif dalam pembelajaran karena hanya mengandalkan guru dalam memahami materi-materi yang diajar.Secara sederhana, pendidikan karakter dapat didefinisikan sebagai segala usaha yang dapat dilakukan untuk mempengaruhi karakter siswa. Tetapi untuk mengetahui pengertian yang tepat, dapat dikemukakan di sini definisi pendidikan karakter yang disampaikan oleh Thomas

Lickona. Lickona menyatakan bahwa pengertian pendidikan karakter adalah suatu usaha yang disengaja untuk membantu seseorang sehingga ia dapat memahami, memperhatikan, dan melakukan nilai-nilai etika yang inti.
Usaha sadar yang dilakukan
oleh seorang guru dapat mempengaruhi karakter yang mereka miliki. Pendidikan karakter tersebut dapat diwujudkan dalam kegiatan proses pembelajaran dengan menerapkan strategi pembelajaran yang dapat membantu siswa untuk mempermudah belajar mereka khususnya mata pelajaran bahasa Indonesia dalam menulis karangan. Penerapan strategi pembelajaran yang akan diterapkan dalam pembelajaran menulis karangan yaitu kombinasi antara strategi pembelajaran SFAE dan ENE.

Dalam hal ini pengusul berupaya untuk memperkenalkan startegi pembelajaran yang mengkombinasikan strategi SFAE dengan ENE dalam mencapai hasil karangan yang baik. Strategi pembelajaran SFAE merupakan strategi yang mengarahkan siswa untuk mempresentasikan ide atau pendapatnya secara inovatif (Purnitawati, 2011:21).Siswa diarahkan untuk menyampaikan pendapatnya setelah mendengarkan penjelasan dari guru.Strategi SFAE dikombinasikan dengan strategi ENE dimana siswa diarahkan untuk memperhatikan sebuah gambar yang ditampilkan dari OHP atau gambargambar dari guru kemudian dituliskan ke dalam bentuk karangan dengan menggunakan strategi pembelajaran SFAE.

\section{METODE}

Pelaksanaan kegiatan dengan memberikan penyuluhan kepada guru yang ada di sekolah SMAN 1 di desa Barus jahe, yang berasal dari sekolah mitra,kegiatan dilaksanakan di luar kegiatan belajar Mengajar agar tidak mengganggu jam pelajaran disekolah dan suasana yang kondusif sangat di perlukan agar kegiatan 
berjalan lancar dan tujuan dari kegiatan ini dapat tercapai. Adapun rincian kegiatan secaragaris besar adalah perencaaan, pelaksanaan tindakan, evaluasi dan refleksi.

\section{HASIL DAN PEMBAHASAN}

Pelaksanaan kegiatan ibM dengan judul "Penerapan Strategi SFAE dan ENE dalam Pembelajaran Menulis Karangan di kabupaten Serdang Bedagai kecamatan Sialang Buah dilaksanakan oleh 1 mitra, kegiatan ini telah dilaksanakan dengan melakukan kegiatan yang yang dicapai sebagai berikut :

1. Melakukan kegiatan sosialisasi kepada Mitra tentang kegiatan pengabdian masyarakat mengenai program ibM ini.

2. Memberikan informasi tentang perpaduan strategi pembelajaran yang diterapkan pada materi menulis karangan khususnya mata pelajaran Bahasa Indonesia.

3. Memberikan penjelasan yang dipaparkan tentang perealisasian antara kedua strategi pembelajaran tersebut yang diterapkan dalam waktu yang sama pada saat pembelajaran berlangsung.

Kegiatan pengabdian kepada masyarakat merupakan hasil dari penelitian yang diterapkan melalui program ibM. Hasil dari penelitian yang diteliti oleh peneliti diturunkan dan diabdikan menjadi kegiatan pengabdian masyarakat. Pelaksanaan kegiatan pengabdian kepada masyarakat dilakukan oleh tim pelaksana dari dosen dan Mahasiswa Universitas Muslim Nusantara Al Washliyah beserta tim panitia yang berasal dari LP2M. Dalam menyelesaikan pelaksanaan kegiatan pengabdian kepada masyarakat tim pelaksana melakukan beberapa tahapan/ langkah-langkah sebagai berikut :

1. Melakukan koordinasi dengan pihak yang terkait

2. Koordinasi yang dilakukan dengan LP2M UMN Al Washliyah dan Aparatur Kepala sekolah beserta guru-guru yang berada di SMK Negeri 1 Teluk Mengkudu dengan pemberitahuan secara tertulis tentang kegiatan yang dilakukan.

3. Melakukan penjadwalan kegiatan yang akan dilakukan Tim pelaksana kegiatan membuat jadwal yang akan dilakukan disesuai kan terhadap kegiatan pemberian penyuluhan atau penjelasan mengenai penerapan strategi pembelajaran SFAE dan ENE dalam materi menulis karangan

4. Melakukan kegiatan yang ditujuh

5. Kegiatan yang dilakukan dengan Mendampingi mitra dalam pemberian materi mengenai penyuluhan penerapan kedua strategi pembelajaran yang diterapkan dalam mata pelajaran bahasa Indonesia

6. Melakukan monitoring dan evaluasi terhadap pelaksanaan kegiatan

Setiap kegiatan yang
dilakukan oleh tim pelaksana kegiatan melakukan monitoring dan evaluasi terhadap kegiatan yang dilakukan sehingga mitra memahami terhadap kegiatan yang dilakukan. Pada saat penyuluhan tentang penerapan kombinasi strategi pembelajaran SFAE dan ENE, masih banyak mitra yang belum mengerti dalam merealisasikan penggunaan strategi pembelajaran yang dikhususkan dalam mata pelajaran bahasa Indonesia. Evaluasi juga dapat dilihat dari kegiatan penyuluhan yang dihasilkan dengan terciptanya suasana kondusif dalam memberikan penjelasan materi tersebut. Guru-guru yang berada di SMK negeri 1 Teluk Mengkudu sangat antusias dalam 
mengikuti kegiatan penyuluhan ini dengan harapan dapat menemukan strategi pembelajaran yang kreatif dan inovatif kepada peserta didik.

Kegiatan pengabdian kepada masyarakat memperoleh apresiasi yang luar biasa dari pihak sekolah di Kecamatan Sialang Buah karena kegiatan pengabdian masyarakat ini membuka pemahaman kepada guruguru tentang penerapan kombinasi strategi pembelajaran yang dapat mempermudah proses pembelajaran yang diajarkan kepada peserta didik khususnya dalam mata pelajaran bahasa Indonesia dengan tujuan menciptakan kegiatan pembelajaran yang kreatif dan inovatif serta menghilangkan rasa kejenuhan siswa dalam kegiatan pembelajaran yang monoton. Kepala SMK Negeri 1 Teluk Mengkudu mengucapkan terima kasih kepada LP2M UMN Al Washliyah sebagai tim pelaksana sekaligus menjadi tim panitia dalam acara ini karena sudah bersedia memfasilitasi guru-guru dalam melakukan kegiatan enyuluhan terhadap penggunaan model pembelajaran.

\section{KESIMPULAN}

Kegiatan pengabdian kepada masyarakat program ibM sudah dilakukan sampai tahapan pemberian pengetahun dan penyuluhan tentang penerapan strategi pembelajaran SFAE dan ENE dalam materi menulis karangan kepada guru-guru yang berada di SMK Negri 1 Teluk Mengkudu. Selanjutnya akan diberikan rencana tahapan berikutnya dalam merealisasikan dalam bentuk pelatihan mengajar kelas kecil atau dengan lain "Microteaching”. Selain itu menerapkan kegiatan pembelajaran dengan menggunakan proyektor agar mencipkan pembelajaran yang menyenangan dan tidak monoton, kemudia mempublikasikan hasil laporan dalam bentuk laporan jurnal ilmiah.

\section{DAFTAR PUSTAKA}

Sanjaya. 2011. Model

Student Facilitator And

Explaining. Jakarta: Grasido.

Prasetyo. 2011. Model

Pembelajaran SFAE dan ENE.

Blogspot.com, diakses

pada tanggal 08 Agustus 2016.

Yunita dalam Purniwati.

2011. Meningkatkan Kemampuan

Kognitif Siswa Melalui

Model Pembelajaran SFAE Pada

Pelajaran IPAKelas V SD Negeri Sei

Rotan. Jurnal PGSD, Vol 1, No 1 tahun 2012:1-10.

Ananta, Wirandya. 2014. Pengaruh

Model Pembelajaran SFAE

Terhadap Kemampuan Pemecahan Masalah Matematika. Jurnal PGSD, Vol 2, No 1, 2014:1- 